\title{
【論文】
}

\section{食品企業におけるホワイトカラー犯罪の発生機制に関する研究 一乳製品製造業者による集団食中毒事件を事例としてー}

京都大学大学院農学研究科 山本 祥平

\section{A Research on Mechanism of Generating White-collar Crime in Food Businesses \\ : A Case Study of a Mass Food Poisoning by a Dairy-products Maker}

\author{
Shohei YAMAMOTO \\ Kyoto University, Graduate School of Agriculture
}

\begin{abstract}
:
Supplied by food businesses, foods could have huge effects on the health of a wide range of consumers, who take in them. For this reason, the work-related deviate behavior of food-business employees may cause extensive and severe health damage. Nevertheless, there are few studies relevant to the issue in Japan. The purpose of this paper is to reveal mechanism of generating deviance of food-business, through a case study of the mass food poisoning caused by the dairy processor on the basis of white-collar crime theory.

I designed a model of the white-collar crime generating mechanism, which focuses on basic requirement of crime (motive, justification, and opportunity), organizational culture, trade subculture, and interaction among these factors. The article analyzed data from the decision and the investigative document of the Public Prosecutor's Office with the model, and obtained the following results.

First, some deviances involve the motive (fear of failure) and justification, which are characteristic of white-collar crimes and which correspond to the above-mentioned model. Second, the leader of a plant, where the deviances occurred, had had a past experience of failure, which amplified his fear of failure at the incident. Third, it was suggested that the leader's fear would have promoted appearance of the plant's organizational culture which gave priority to cost reduction over product safety. However, I did not verify that the organizational culture existed in the third point. Additionally, the case included a particular type of deviance which the model cannot explain, which needs to be modified. These issues remain to be solved.
\end{abstract}

Keyword: compliance, food safety, mass food poisoning, white-collar crime, motive, justification, organizational culture 


\section{1. 研究課題と分析方法}

近年、日本において、食品企業やその従業員に よる違法行為が多発している。一般に企業やその 従業員による違法行為は、個人による街頭犯罪と は比較にならないほど大規模かつ広範な被害を社 会にもたらすことがあるが、特に食品企業は人間 の健康に影響を及ぼす食料品を扱っているため、 身体への被害をもたらす恐れがある。したがって、 食品企業やその従業員による違法行為を抑止する ことは、深刻な被害と社会不安を未然に防ぐこと に繋がるものであり、極めて重要な問題である。

以上の問題意識から、食品企業とその従業員に よる違法行為に対する有効な防止策を開発するた めに、本論文ではまずその発生機制を解明するこ とを目的としている。またこれを達成するために 本論文では、次の 3 つの課題を設定した。その 1 つは、企業やその従業員による違法行為を説明す る、ホワイトカラー犯罪の概念を整理することで

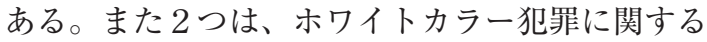
理論を整理し、その発生機制を分析するための一 般モデルを作成することである。以上は先行文献 の研究を通じて行われる。そして 3 つは、平成12 年 6 月に発生した乳製品製造業者による集団食中 毒事件の発生機制を解明し、第 2 の課題で作成し たモデルと事例との整合性を検討することである。 この課題は当該食中毒事件に関する既存文献だけ でなく、当該事件の判決文や検察官面前供述調書 などの一次資料を分析することで検討される。

\section{2. ホワイトカラー犯罪の概念の定義}

ホワイトカラー犯罪は、E. H. Sutherland によっ て提唱された概念であり、「名望ある社会的地位 にある人物が、その職務上犯す違法行為」と定義 される $[1]$ 。だが概念が提示されて以来、その 範囲があらゆる職業の人物の犯罪を含むのか、そ れとも名望ある社会的地位にある人物の犯罪に限 定するかを巡り、混乱が生じた経緯がある $[1]$ 。 これに対し、Clinard ら［2] はホワイトカラー 犯罪の概念を業務犯（Occupational Crime）と企
業犯 (Corporate Crime) に分類し、概念の混乱 を沈静化しょうと試みたが、新田 [1] や Coleman [3] によれば、この二分法が、常識的 に受け入れやすいため犯罪学者たちの間で定着し ているとされる。したがって本論文では、 Clinard らの二分法を用いて定義を規定する。た だし、その際に、Colemanの見解に従い、「企業 犯」に替えて「組織体犯罪」の用語を参照し、企 業以外の組織体による犯罪を扱えるようにする (註 1 )。以上より、本論文ではホワイトカラー犯 罪を「合法的な職業に従事している単数または複 数の個人が、自らの利益のためにあるいは組織体 の利益を実現すべく、業務や組織を悪用して行う 作為の犯罪行為、ないし業務に関連する不作為の 犯罪行為」と定義した。

この定義は、犯行主体が合法的な職業に従事す る限り、その社会的な地位に拘らず、その犯行を 対象とする事ができる。ただし、合法的な職業に 従事する者の犯行であっても、業務と関係ない場 合は除外する。また本論文の定義は、組織体犯罪、 職務犯罪、およびその双方の性質を併せ持つ混合 犯罪を包摂しており、さらに作為、不作為の犯罪 行為を含む。なお、「犯罪行為」という文言には、 Sutherland [4] の犯罪に対する見解を参照し、 「社会的に有害であることの法律上の規定」が存 在し、かつ「該行為（当該行為－引用者）に対す る処罰につき法律の規定が存する」全ての法侵犯 行為という意味を持たせている。

\section{3. ホワイトカラー犯罪の発生機制の一般モ デル}

1 ）ホワイトカラー犯罪および組織体犯罪に関す る諸理論

新田はホワイトカラー犯罪の発生機制を、井上 ［5］は組織体犯罪を説明しているが、そのため の個々の理論は、部分的に重複や類似がある。本 論文では、それを整理し、モデルに必要な理論と して、「犯行動機」、「犯行の合理化」、「犯行機会」 「逸脱の準備性形成」「組織における負の組織文 化の表出」に関する理論、「差異的接触理論」を 取り出した。これらについては以下で論じるが、 
整理の過程は割愛する。

\section{2 ）モデルで参照した理論および概念の説明}

まず犯行動機、犯行の合理化、犯行機会につい て説明する。Colemanは、犯行を成立させる基本 的な条件として動機と機会の 2 つを挙げ、動機を 「個人を犯罪へと誘導する動機の形成」と「犯行 を抑制する社会的な倫理基準の無効化」との $2 つ$ に区分している。前者が「犯行動機」であり、後 者が「犯行の合理化」と呼ばれるものである。

さらに新田によれば、Colemanは犯行動機には 主として「達成動機 (the desire to achieve)」と 「失敗恐怖 (the fear of failure)」があることを指 摘している（註 2 ）。達成動機とは、自分の現状 の地位・収入で满足せず、一層の利益追求と昇進 とを目指そうという感情のことである。一方、失 敗恐怖とは、地位の峦失、自尊心の損傷、および 事業の崩壊などの既得のものを失うことに対する 不安のことである。

犯行の合理化については、新田によれば、D. R. Cressyがそのパターンを明らかにしている。 それによれば、ホワイトカラー犯罪の犯行主体は、 「自分のためではない、会社の生き残りをかけて ピンチから救うのだ (献身)」や「違法なことは わかっている、法律が実情にあっていないのだ (必要悪)」といった同犯罪特有の手法での合理化 を行うとされている $[1]$ 。また本論文では、自 己正当化による社会的な倫理規範の無効化だけで はなく、特定の利害に基づく、自己のおかれてい る環境認知の操作や $[5]$ 、派閥メンバー間の連 帯感の形成による罪悪感の希釈という現象 [1] なども、犯行の合理化と位置付けている（註 3 )。

犯行機会についてだが、新田によれば、業務上 犯罪は豊富な実務経験を有し、上司からもその能 力を信頼されている中間管理職が最も犯行機会に 恵まれる（註 4 ）。また組織的犯罪では高度な業 務上の知識と経験を有し、かつ組織内の機密情報 に接近し犯行の意思決定に関与できる立場にいる ような、組織内での地位の高い人物が機会に恵ま れる（註５）。また、前島［6］［7］は、生活運 行理論における犯罪要素の分類を参考に、犯行機 会を「相応しい標的が存在する機会」と「効果的
な監視人が欠如する機会」の 2 つで捉えている。 後者は、上司が部下の行動に対し、適切な介入や 管理を行わない場合に発生し得ることが指摘され ている [6]。

続いて「差異的接触理論」について説明する。 「差異的接触理論」は、Sutherlandが犯罪発生を 説明するための普遍的な理論として提唱したもの である。それによれば、本来人間は法規範に対し て否定的な態度よりも肯定的な態度が強いという。 しかし、法規範に対して否定的な態度の強い人物 と接触した場合、接触の仕方に応じて犯行の技 術・動機・合理化を学習し、反社会的な価值に染 まり、犯罪行為に走るケースが生じ得る。

「逸脱の準備性形成」についてだが、これは新 しく企業に入社した幹部候補生が、自身の自我意 識を抑えて協調性を養い、企業のインフォーマル な論理を自己内在化させ、組織的犯罪者としての 犯行の準備性を形成していく過程を描写する理論 である。新田によれば、この過程を通して育成さ れた企業の幹部は、非公式な組織の論理に従い、 違法行為を犯すようになり得る。

\section{3 ) 組織文化・業界下位文化}

ホワイトカラー犯罪は組織全体に共通する規範 や慣習などによって引き起こされ、助長され得る という視点を導入すると、組織文化の概念や、業 界下位文化なる概念を見出すことができる。

本論文では、飯田 [8] の提示した組織文化概 念の類型に基づき、組織文化を「各個別組織体の 構成員が共有している全ての潜在的及び顕在的な 意思決定基準」と定義する。

また業界下位文化とは、前島が職務犯罪を分析 する際に導入した概念であり、「各個別業界のメ ンバー (同業者仲間) が共有しているすべての意 思決定基準（価值観、信念、理念、規範など）」 と定義されている $[6]$ 。本論文では、前島の定 義を援用し、これを「各個別業界の構成員が共有 している全ての潜在的及び顕在的意思決定基準」 と定義する。

新田による「組織における負の組織文化の表 出」の議論に従えば、本来企業は、社会的規範に 従って運営すべきという価值と、自らの利益を最 
優先すべきという価值を備えている（註 6 ）。通常、 企業は公益侵害者のイメージを避けるために、営 利本位の価值を抑えるよう価值調整を行っている。

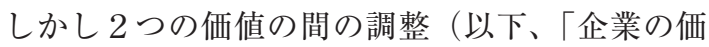
值調整」）が困難になるような状況に陥ると、調 整は破綻し、違法行為も辞さないとする姿勢が組 織全体に行き渡ることにもなり得る。

さらに本論文ではSutherlandの差異的接触理論 のホワイトカラー犯罪への適用仮説を用いて、組 織文化、業界下位文化の関係性について以下のよ うな仮定を行う。すなわち、一企業が負の組織文 化を体現させた経営を行い、それによって競争優 位性を確立した場合、違法行為に手を染めかねな いような組織文化が他企業に伝播していき、最終 的に負の業界下位文化を形成することがあるとい うものである。

4）本論文におけるホワイトカラー犯罪の発生機 制のモデル

以上の整理を基に設計したホワイトカラー犯罪 の発生機制のモデルを示したものが図 1 である。 このモデルで最も重要な部分は、図の中程にある
「犯行動機」、「犯行の合理化」「犯行機会」の三 項目であり、この 3 つが揃ったときに犯行が成立 し得ることを想定している。これらの基本条件の 内容は先述のとおりである。

またこのモデルでは、これら犯罪成立の基本条 件が、「企業の価值調整」が困難となったときに 表出する可能性のある組織文化・業界下位文化に よって、以下の影響を受け得ることを仮定してい る(註 7$)$ 。

(1)負の組織文化・業界下位文化そのものが犯行動 機の一部として作用する場合がある。

(2)組織文化・業界下位文化が犯行動機である「達 成動機」「失敗恐怖」を増幅することがある。

(3)組織文化が犯行の合理化を助長し、犯行機会を 創出する場合がある。

(4)業界下位文化が犯行の合理化を助長し、犯行機 会を創出する場合がある。

犯行成立の基本条件が揃うとき、犯行が成立す る可能性があるが、それが組織の利益のために組 織全体を活用したのであれば組織体犯罪となり、 個人の利益のために業務を利用したのであれば職 務犯罪となる。また、2つの性質を併せ持つ犯行

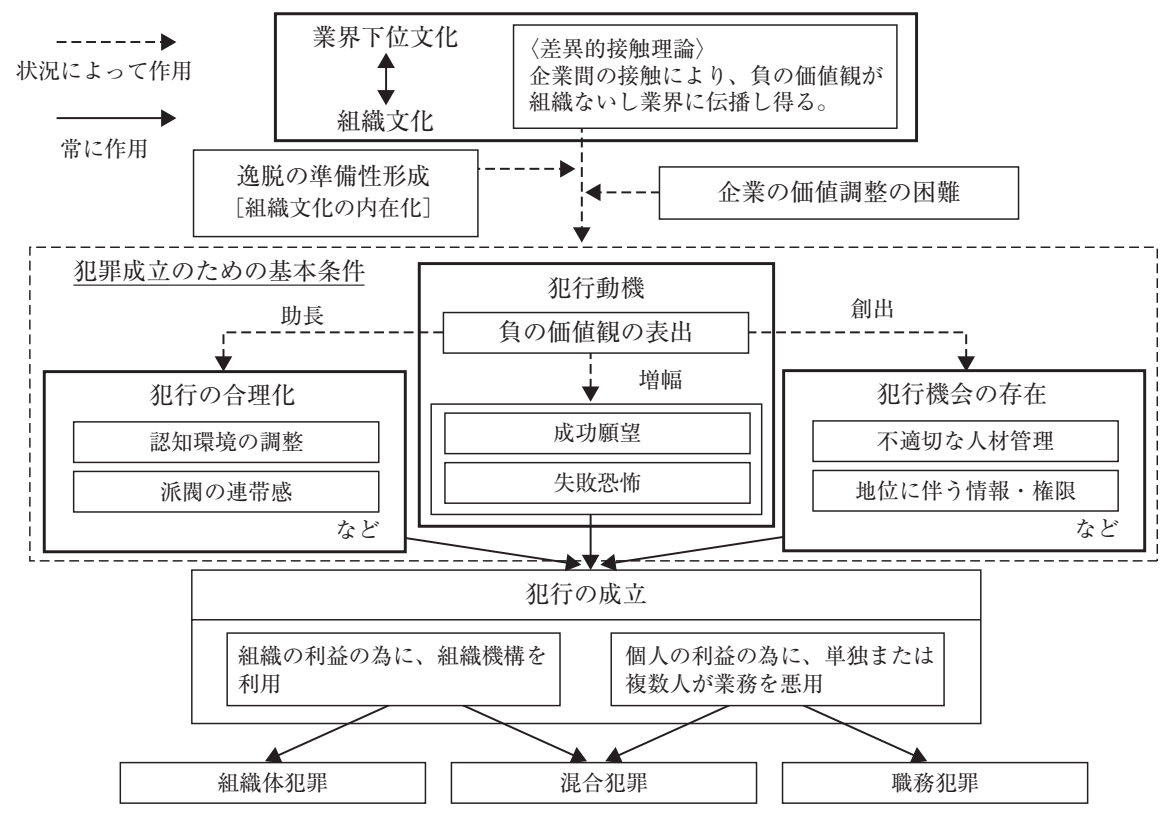

図1 ホワイトカラー犯罪の発生機制モデル

註：新田、井上、前島、平岡［14］を参考に作成。 
がなされれば、それは混合犯罪となる。

なお上記のモデルは、ホワイトカラー犯罪の発 生機制の一般モデルである。もし食品企業の犯罪 に特殊性があるなら、そのまま適用するには問題 があろう。しかし食品企業の犯罪に関する研究事 例はそしく、既存の研究成果を用いてその特殊性 や一般モデルの適用可能性を議論することはでき ない。そこで本論文では、上記の一般モデルを適 用し、その結果の蓄積から適用可能性や特殊性を 判断する方法をとった。

\section{4. 事例分析}

\section{1 ）課題の限定とデータ}

本論文では以上のモデルに従って事例分析を行 う。ただし本論文では、データの制約から 3 つの 基本条件の存在に検証の中心をおき、基本条件に 対する組織文化、業界下位文化の影響については 示唆にとどまる。組織文化および業界下位文化の 存在やその形成過程については別の検証が必要で あり、それは今後の課題としたい。なお事例は、 平成12年 6 月に発生した乳製品製造業者による集 団食中毒事件とする。

また事例分析のデータは、藤原 [9]、産経新 聞取材班 [10]、判決文 [11]、検察官面前供述調 書 [12（以下「調書」と略記）に依拠している。 判決文と調書は、検察庁に閲覧申請をし、許可を 得て閲覧した一次資料である。ただし調書に関し ては、閲覧を許可されたもののうち当該事件に深 く関与した北海道の工場（以下、工場 A）の工場 長の供述部分のみを用いた。

なお調書は、被告人の犯罪に関する供述を含む ため、元被告人を特定する情報と結び付けば、そ の更生や生活を妨げる恐れがある。そのような趣 旨において、調書の閲覧に際し検察庁と交わした 誓約の遵守のため、また道義的責任の点から、本 論文では元被告人のプライバシーを侵害する形で 調書を利用するわけにはいかない。そこで本論文 では、犯行の心理的要因を探るために、やむなく 調書に依拠したが、所属企業や部署を伏せ、供述 内容についても「企業人」としての行動・思考を 示す部分のみを用いた。また、仮に拙稿を参照さ
れる場合には、元被告人の権利侵害に繋がらない よう十分に注意をお願いしたい。

\section{2 ) 事件の概要}

本論文で取り上げた、乳製品製造業者（以下、 業者A）による集団食中毒事件は、6月25日に大 阪市および和歌山県内で業者 $\mathrm{A}$ の低脂肪乳を摂食 した児童が嘔吐・吐気を訴えるという形で幕を開 けた（註 8$)$ 。これ以降、同社の大阪に所在する 工場（以下、工場 B) で製造された低脂肪乳の摂 食に起因すると見られる食中毒の発生が、業者 $\mathrm{A} \cdot$ 大阪市保健所に相次いで報告され、最終的に は、報告された有症者は約14,000名に達した。

事件発生から 5 日後の 6 月30日には、和歌山市 衛生研究所において、食中毒患者の低脂肪乳の飲 み残しから黄色ブドウ球菌毒素遺伝子が検出され た (註 9$)$ 。さらに 2 日には、大阪府立公衆衛生 研究所が、低脂肪乳からエンテロトキシンを検出 し、これによって当該事件の原因物質がエンテロ トキシンであったことが明らかとなった（註10）。

事件発生当初から、業者 $\mathrm{A} 、 大$ 阪市、厚生労働 省は、当該事件の原因究明に向けて調査を行って きたが、遅々として進まなかった。結局、事件の 直接の原因が明らかとなるのは、事件発生から 1 ケ月以上経過した 8 月18日のことである。この日、 大阪府警が、低脂肪乳に使用されていたとされる、 工場 $\mathrm{A} て ゙ 4$ 月 10 日に製造された脱脂粉乳からエン テロトキシンが検出されたとの情報を大阪市に通 報し、同市が事実を公表した。また翌19日には、 北海道带広保健所が工場 $\mathrm{A}$ に入場し調査を行った が、その結果 4 月 10 日製造脱脂粉乳は、4月 1 日 製造脱脂粉乳を再溶解して製造された点、および 3 月31日の停電事故の影響で 4 月 1 日製造脱脂粉 乳がエンテロトキシン $\mathrm{A}$ に污染されたとの推定が 出された。

上記の捜査で得られた情報を基に、大阪府警は 平成13年 3 月 16 日に、業者Aの従業員を業務上過 失致死傷の容疑で書類送検した。そして同年12月 18日に、業務上過失致死傷、および食品衛生法違

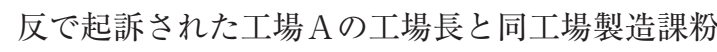
乳係主任の第 1 回公判が大阪地方裁判所で行われ た。当該事案の判決公判は平成15年 5 月 27 日に大 
阪地方裁判所にて開廷されたが、判決文によれば、 両者は業務上過失傷害ならびに食品衛生法違反の 罪で裁かれ、執行猶予付きの有罪判決が下されて いる。

3 ）本論文でホワイトカラー犯罪として分析する 工場 $\mathrm{A}$ における不正行為

当該事件には、業者 $\mathrm{A} に よ る$ 複数の犯罪、違法 行為が内包されているが、本論文では以下の(1)か ら(3)の 3 件に限定して分析を行う。

(1)業者 $\mathrm{A}$ の工場 $\mathrm{A}$ において、平成12年 3 月31日 に起きた停電事故の際、工場長が冷却されない洗 い汁を放置することで、4月 1 日製造脱脂粉乳を エンテロトキシンで污染させた件（業務上過失傷 害)。

(2)上記工場において 4 月 1 日製造脱脂粉乳を原 料として再利用することで、10日製造脱脂粉乳を エンテロトキシンで污染させ、当該脱脂粉乳の出 荷を工場長が許可した件（業務上過失傷害）。

(3)上記工場において、工場長の指示により 7 月 上旬ごろから作業記録の改ざんが行われ、その結 果作成された記録が平成12年 7 月 13 日および 8 月 19日に保健所に提出され、虚偽の報告がなされた 件 (食品衛生法違反)。

\section{4）各不正行為の発生の経緯}

まず前節の事案(1)の経緯について説明する。平

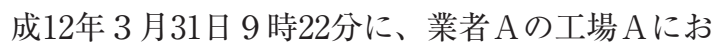
いて、停電事故が発生した。その時、同工場では 脱脂粉乳製造ラインの濃縮機等を洗浄した際に発 生した「洗い汁」が、専用タンクに回収され、冷 却されていた（註11）。10時57分、工場長らは、 停電事故の発生を確認した。このとき同工場の濃 縮乳タンク等の機器には開放部があるため、そこ から黄色ブドウ球菌が混入しうる状態であり、ま た10時57分時点でタンク内の洗い汁の温度は $36^{\circ} \mathrm{C}$ で、黄色ブドウ球菌の最適繁殖温度であったので、 工場長らには、洗い汁中でのエンテロトキシンの 産生を予期し、製品が污染されるのを防止すると いう注意義務が存在した。しかし、工程の巡視や 洗い汁の冷却確認を行わないまま放置した。13時 49分には工場 $\mathrm{A} の$ 電力が一部復旧し、循環冷却機
の使用が可能になったが、工場長らが洗い汁に対 して適切な措置を講ずることはなかった $[11]$ 。 19時44分に工場の電力は完全に回復した [9］。 それと同時に、工場 $\mathrm{A}$ 内の全作業工程が稼動し始 め、タンク内に冷却されずに残っていた洗い汁が 製品原料の一部として使用され、4月 2 日頃にエ ンテロトキシンに污染された 4 月 1 日製造脱脂粉 乳が生産された $[11]$ 。

続いて事案(2)の経緯について説明する。4月 4 日、工場 $\mathrm{A} の$ 品質管理室が 4 月 1 日製造脱脂粉乳 の細菌数検査を実施した［9］［12］。その結果、 同脱脂粉乳からは最大で $1 \mathrm{~g}$ あたり11,000個もの 生菌が検出された。同工場の通常の検查結果は、 生菌数が $1 \mathrm{~g}$ あたり 0 ～10個であることを考える と、この数值は極めて高い異常な数值であった [11］。このため、同工場では充填・包装された製 品の中からさらにサンプルを抽出し、微生物検査 を実施し、8日までに得られた結果をもとに、4 月 1 日製造脱脂粉乳の前半までを製品計上して、 残りを脱脂粉乳の原料として再溶解することが決 定された。そして 4 月 9 日から10日にかけて、上 記の 4 月 1 日製造脱脂粉乳が溶解・添加され、同 脱脂粉乳中に存在していたエンテロトキシンが 4 月 10 日製造脱脂粉乳に混入した［9］。4月12日、 工場長は 4 月 1 日製造脱脂粉乳から異常な数の生 菌が検出されたこと、および同脱脂粉乳の一部が 4 月 10 日製造脱脂粉乳に再溶解されたことを、部 下からの報告書で知った。このとき工場長は、4 月 1 日製造脱脂粉乳の細菌数異常は二次污染であ るとの報告を受けた（註12）。工場長は後日、細 菌数異常が二次污染によるものではないことは自 らの知識を以ってすれば理解できたと供述してい るが、12日の時点では、二次污染か否かを確認す るのに必要な総菌数検査などの措置を講じず、出 荷を許可した [12]。これにより4月11日から12 日にかけて、4月10日製造脱脂粉乳が工場 Aから 出荷され、そのうちのが工場 Bへと搬入され、同 年 6 月 20 日から 25 日にかけて当該脱脂粉乳が低脂 肪乳の原料として使用されたのである [11]。

最後に(3)の事案の経緯について説明する。平成 12 年 6 月 28 日、工場 $\mathrm{A}$ の場長は業者 $\mathrm{A}$ の製品に よる事件が発生しているとの情報を掴んだ。また 
翌29日に工場長は当該事件が集団食中毒事件であ ることを知った。工場長は、保健所の立入検査が あった場合に何らかの不備があれば、工場の評価 が下がり、製造機器の使用禁止処分を受けること を強く危惧したため、29日、30日の両日、部下に 機器類の洗浄を行うよう指示した。7月 5 日、工 場長は工場 $\mathrm{A}$ で製造された脱脂粉乳が工場 $\mathrm{B} て ゙$ 使 用されていた情報を入手した。また翌 6 日には工 場 Bで使用されていたのは、4月10日製造脱脂粉 乳であったとの報告を受けた。工場長は、すぐに ロットサンプルを利用して 4 月 1 日と 4 月 10 日製 造の脱脂粉乳の総菌数検査を実施したが、前者か ら最大で $1 \mathrm{~g}$ あたり 3,500 万個、後者から最大で $1 \mathrm{~g}$ あたり 1,200 万個検出され、工程管理目標を 満たしていないことと 4 月 1 日製造脱脂粉乳の細 菌污染が二次污染でないことが明らかとなった。 これを受け工場長は、両脱脂粉乳の污染原因の究 明を部下に指示したが、工場 $\mathrm{A} の$ 作業記録の管理 が杜撰であったため進展しなかった。

また 7 月 6 日には、東京に所在する業者 Aの工 場で保健所の立入検査があり、当該工場で貯乳夕 ンクの洗浄記録がないことから当該タンクの使用 が禁止された事実が、工場長の知るところとなっ た。これにより工場長は、工場 $\mathrm{A} の$ 杜撰な記録管 理が保健所に知られたら、操業停止になりかねな いとの不安を抱き、7月 7 日に工場 $\mathrm{A} の$ 全職場に 作業記録の捏造を指示した。これに対し翌 8 日に は一部の職場から捏造に対する批判が噴出するも、 工場長は記録の改ざんを再度指示した。そして、 7 月13日および 8 月19日の立入検査の際に、保健 所に改ざんした記録を提出し、食品衛生法で禁止 されている虚偽の報告を行った $[12]$ 。

5 ）各不正行為の発生機制分析の方法と結果

以下では工場 $\mathrm{A}$ の場長自身の供述に基づいて 上記の(1)〜 (3)の事案の発生機制の分析を行う。

その方法であるが、調書の犯行時の工場長の心 理状態の記述について、それが行動の目的や理由 を示すならば、「犯行動機」として捉えた。そし て新田が示した「成功願望」や「失敗恐怖」の動 機の具体例と照合し、犯行動機を分類した。また 心理状態の記述が、自身を納得させるためのもの
ならば、それを「犯行の合理化」と把握した。

シャイン [13] によれば、組織文化は、組織の 外部者と内部者の相互作用を通じて明らかとなる。 したがって調書の分析のみでは、その存在を立証 することはできない。しかし本論文では、社員間 に共通した態度や考え方がある場合には、それを 組織文化の存在の示唆として捉える。さらに、そ れが犯行を惹起し得るものと考えられる場合には、 負の組織文化の存在の示唆として捉える。

なお、事案(2)、事案(3)発生機制については図 2、図 3 にまとめている。

\section{・第 1 事案}

事案(1)の発生機制を以下に示す。

工場 $\mathrm{A}$ の場長が、停電事故発生時に長時間放 裹した洗い汁にエンテロトキシンが産生した可能 性を認知しながら、必要な措置を講じなかった背 景には、不良品を製造し、会社に損害を与えれば、 それは明白な失態であり、上司から叱責され、会 社からの評価も落ちるという心理があった [12]。 この心理は失敗恐怖にあたると考えられる。

工場長の失敗恐怖は過去の失敗の経験により増 幅されたものであると推測される。工場長は、平 成11年に工場 Aでホエー粉を製造していた際に冷 却機プレートが破損し冷媒がホエー粉に混入する という事態に見舞われ、ホエー粉を廃棄し、約 1700万円の損失を出した。この際、工場長はホエ 一粉の廃裹について本社役員に禀議書を、支社に 始末書を提出せねばならなかったため、「二度と 失敗は犯せない」という強い意識が芽生えたとさ れている。

上記のように増幅された工場長の失敗恐怖はま た、工場 $\mathrm{A}$ 内において製品の安全よりもコスト削 減を優先する組織文化を現出させる一因ともなっ たと考えられる（註13）。工場長は、二度と失敗 をしないために、指定されたコストの超過につい ては、数千円単位でも原因を究明するという徹底 したコスト管理体制を敷き続けた結果、製品の安 全性を重視するという姿勢よりもコスト削減を重 視するという姿勢が強くなったと供述している。 そして、工場長の主だった部下たちも工場長から コスト削減を厳しく指導された結果、製品の安全 
性よりもコスト削減を重視する姿勢に偏ったとの 工場長の供述が見られる $[12]$ 。

このように調書を見れば、事案(1)の背景には上 司からの叱責と会社からの評価の低下への恐怖感 (失敗恐怖) や生産効率優先の姿勢があったこと が記述されている。しかし、これらが注意義務違 反を直接に発生させたとは考えにくい。むしろ上 記の感情および姿勢を持っていれば、工場長は寧 ろ積極的に注意義務を果たすように行動する可能 性が高いとも考えられるからである。注意義務違 反が生じた実際の原因は、下記に示した通りであ ると考える。

上記の「失敗恐怖」に駆られていた工場長は、 停電事件を知った時、停電がチーズの製造中ある いは脱脂粉乳の濃縮中に起こったのかどうかを強 く懸念した。そこに部下から停電時にはこれらの 作業を行っていなかったとの報告を受け、工場長 は最大の懸念が回避できたとの安堵感を覚えた。 工場長はこの時、洗い汁の冷却不能による細菌増 殖の可能性が意識に上っていたが、洗い汁は部下
に任せれば適切に処理・廃棄されるだろうと考え、 それが原料として使われる可能性を軽視し、部下 に確認の指示も行わなかった。一方で工場長から 「適切な処理」を期待されていた部下の方では、 停電事故によって中断した生乳の受入れ作業で頭 が一杯であったため、洗い汁については大丈夫で

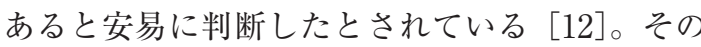
結果、同工場における脱脂粉乳のエンテロトキシ ン污染が発生したと考えられる。

このように発生機制を見れば、本論文の仮説モ デルで取り上げた諸要素を以って説明することは 困難であることが分かる。上記の類の逸脱行為を 分析するための枠組み構築が研究上の課題となる であろう。

\section{- 第 2 事案}

事案(2)における工場長の犯行動機は、不良品を 製造し損害を出せば、上司や会社からの評価を落 としてしまうという心理だった [12]（図 2)。事 案(1)とは異なり事案(2)では、この失敗恐怖の感情

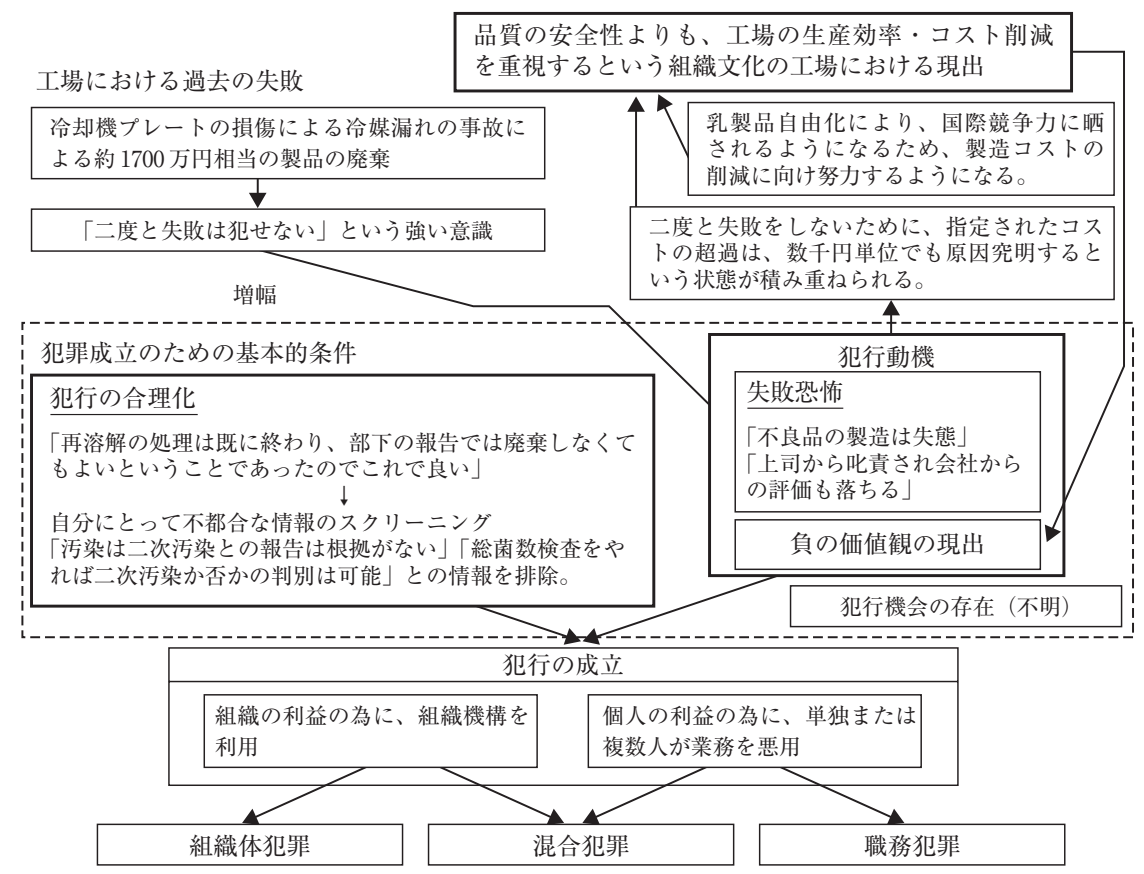

図2工場 $\mathrm{A}$ における污染脱脂粉乳の再溶解と出荷の発生機制

註：調書より作成。 
が直接に犯行動機となったと推測される。また前 述した製品の安全性よりも生産効率を優先すると いう組織文化も動機となったと見られる。この組 織文化の現出には、工場長が乳製品自由化に伴っ て激化するであろう国際競争に備え、日々製造コ ストを削減し続けたことも一因となったとの工場 長の供述も見られる。

犯行の合理化については以下のように把握され る。前 4 ）項のように、4月 12 日、工場長は 4 月 1 日製造脱脂粉乳から異常な数の細菌が検出され た件と、その原因は二次污染であるため製品の廃 裹は必要ないという点について部下から報告を受 けた。工場長はこのとき、「原因は二次污染であ る」とする部下の報告には根拠がなく、また二次 污染か否かは総菌数検査を行えば判別できること を認識していた。しかし工場長は「(再溶解の) 処理が終わって、廃裹はしなくてもよいという結 果だかられでよい（部下の意見を採用しても良 い)」と考え、総菌数検査を実施せず、部下の主
張を受け入れ、出荷を容認した。もっとも総菌数 検査を実施し、細菌数が報告されても結果は変わ らなかっただろうと工場長は供述している。また 工場長は、 4 月 1 日製造脱脂粉乳の 10 日製造脱脂 粉乳への再溶解の比率が通常よりも高いことに気 づいたが、それも作業を終わっていたことを理由 に考えないこととした。以上より、工場長は部下 の報告と、既に再溶解作業が終わっていることを 理由として、総菌数検査の実施の必要性などの自 分に不都合な情報を考えないようにすることで、 犯行の合理化を行っていると推測される。

\section{・第 3 事案}

7 月 6 日に、東京に所在する業者Aの工場への 保健所の立入検査の一部始終を知った工場 $\mathrm{A}$ の 場長は、記録管理が杜撰な工場 Aに保健所が入れ ば操業停止や施設の使用禁止処分になりかねず、 そうなれば莫大な損失が生じ、自身の責任が問わ れると考え、犯行に及んた（図 3 )。したがって

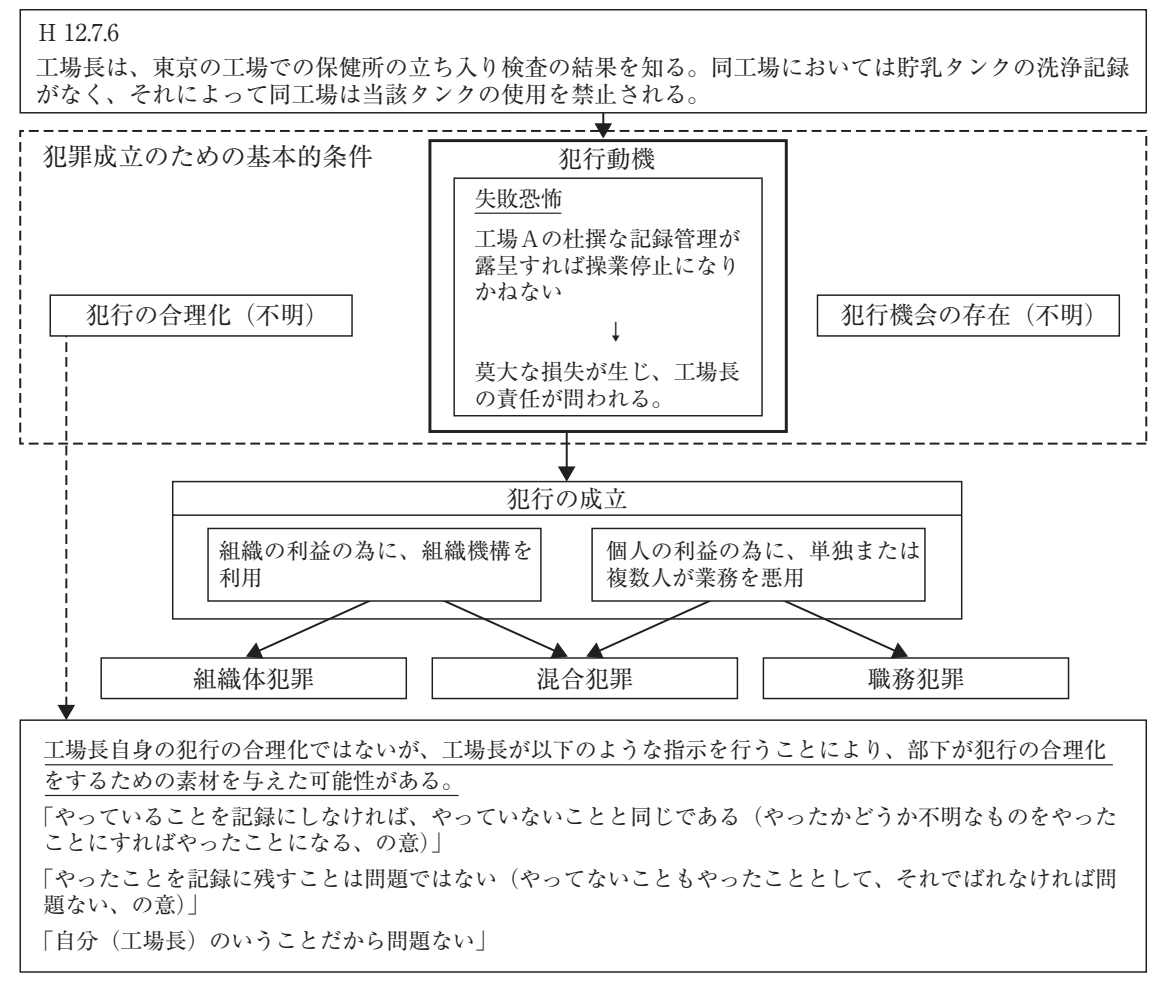

図３工場 Aにおける洗浄記録改ざんの発生機制

註：調書より作成。 
事案(3)に関する工場長の犯行動機も、失敗恐怖で あったと考えられる。

事案(3)において工場長が自身の犯行を合理化し た供述については、調書には記されていなかった。 だが工場長が 7 月 7 日に部下に対して洗浄記録の 不備を隠すために記録の捏造を指示したときに行 った、合理化と考えられる言動については以下の ものが見られた。すなわち「やっていることを記 録にしなければ、やっていないことと同じである」 (やったかどうか不明なものをやったことにすれ ばやったことになる、の意)、「やったことを記録 に残すことは問題ではない」（やっていないこと をやったことにして、それでバレなければ問題な い、の意）の 2 つである。また 7 月 8 日に一部の 職場から改ざんではないかとの反発が出た際には、 工場長は「自分 (工場長) の言うことだから問題 ない」と説明し、再び部下に対する犯行の合理化 を行っていると考えられる [12]。

なお、事案(3)の発生機制と工場 Aにおける組織 文化との関係については、少なくとも調書からは 読み取れなかった。

\section{5. 結論と今後の課題}

本論文では、犯罪学分野のホワイトカラー犯罪 研究を参考に、食品分野のホワイトカラー犯罪の 定義とその発生機制の一般モデルを設計した。そ して平成 12 年 6 月末に発生した乳製品製造業者に よる集団食中毒事件を事例として、供述調書など をもとにモデルと事例との整合性を検討した。

発生機制モデルと事例の発生機制とが一致した のは、i）失敗恐怖というホワイトカラー犯罪に 特徵的な犯行動機の存在、 ii ）犯行の合理化の存 在である。iii）犯行機会については、調書のデー 夕からは明らかにすることができなかった。

また、供述からiv）製品の安全性よりもコスト 削減を優先する組織文化が形成されたことが示唆 され、さらにそれが犯行動機に影響を与えたこと が示唆されたが、充分な実証にはいたっていない。 このような組織文化の存在については、別の方法 での測定や形成過程の分析を通じて、今後検証し ていくことが必要である。
さらに、事例の発生機制の分析から新たに判明 したのは、i）失敗恐怖というそれ自体では犯罪 に結びつかない感情が、組織文化によってではな く、過去の個人的な失敗の経験から増幅され、犯 行動機となることがあり得るということである。 また他方において、 ii ）組織文化に影響を与えう る人物の失敗恐怖が、組織文化の現出を促す要因 となることがあることが考えられたことである。 本事例に扮いては調書の供述から、i）不良品を 出し、会社に損害を与えれば叱責されるという失 敗恐怖が、過去の大量廃棄により大きな損害を出 し強く叱責された経験によって増幅されたこと、 ii ）やはり過去の失敗恐怖から徹底したコスト管 理体制を敷き、製品の安全性よりもコスト削減を 重視する姿勢が工場内で共有されたことを見出し た。

上記より、本論文のホワイトカラー犯罪の発生 機制モデルは、犯行動機、犯行の合理化の点で見 れば当てはまりが良く、食品企業の犯罪への適用 可能性を示唆している。しかしモデルの構成要素 には、検証が不十分なものも多く、モデルで想定 していない現象も確認された。ゆえに、全面的に 適用可能と断定するには課題が多いと言える。

今後の課題としては以下の事項が残された。

まず今回分析を試みた事例の中には、本論文で 構築した仮説モデルでは説明することが困難なも のが存在した $($ 事案(1)）。このような業務上の「過 失」という形態を取る犯罪を分析する手法を作る ことが必要となるだろう。

次に、本論文では、犯行成立の基本条件のうち の犯行機会について検討することができなかった。 したがって犯行機会に関する先行研究をさらに整 理し、当該事例においてはいかなる事項が犯行機 会として作用したかを、考察することが必要であ ろう。

さらに今回の事例分析では工場 $\mathrm{A}$ 内における組 織文化の現出が示唆されたが、業者 $\mathrm{A}$ 全体の組織 文化㧍よび乳製品業界の業界下位文化の存在およ び形成過程という重要な問題には分析が及ばず、 また工場内の組織文化とそれらとの関係も分から なかった。この点も今後の課題である。

また、今回の事例において、失敗恐怖や、利益 
を安全性に優先する組織文化などの犯行の要因の 存在が観察ないし示唆されたが、これらの要因の 存在が、確定的に犯罪を発生させるわけではない。 今後は、これらの要素が犯行に結び付く条件・状 況を探索する必要がある。

加えて、食品企業による犯罪の特殊性も明らか にならなかった。これも残された課題である。

本研究は、食品分野のホワイトカラー犯罪の発 生機制を明らかにすることを課題とし、しかも端 緒的な研究であるので、そこから現実の改善に提 供できるインプリケーションは限られたものであ るが、以下の点が指摘できる。

食品安全に関しては、ミスが的確に指摘され、 再発しないように改善措置を取ることが不可欠で ある。しかし、ミスに対する叱責が過度になると、 本事例にみるように失敗恐怖に陥り、叱責を恐れ るあまりミスを隠す行為に走らせ、製品の安全が 損なわれ、著しい健康被害を発生させる可能性が ある。無論、厳しい叱責から来る失敗恐怖が必ず しも犯罪につながるわけではないし、適切な指摘 と過度の叱責の境界を明確にすることは難しいか もしれないが、ミスが直ちに報告され、製品の安 全確保が優先される管理体制を作ることが重要で あると考えられる。

(註 1 ) 組織体犯罪とはSchrager \& Shortが提唱した 概念である。井上によればその定義は「合法的な フォーマルな組織において組織目標にしたがって、 個人あるいは複数の個人によってなされる作為あ るいは不作為の不法行為」である。Colemanは、 Clinardらの二分法のうちの「企業犯」を組織体 犯罪概念に置き換えることを提案している。

(註 2 ) ホワイトカラー犯罪の犯行動機が常に達成動 機と失敗恐怖のいずれかであるとは限らない。中 には、逸脱の快感を楽しむという動機や、不満な 上司への意趣返しという一般犯罪と同様な動機の 下で犯行がなされることもある。

(註 3 ) 井上によれば、組織の意思決定者は経営環境 の認知に際して、特定利害に基づいて情報をスク リーニングし、自分に有利な情報のみを残して、 不利な情報を無視し、外部に対して隠蔽するよう になる。

（註 4 ）業務上犯罪とは「個人または複数個人が自ら
の私欲を充たす目的で、自己の地位・役割に伴う 業務を悪用して行う犯行」のことである $[1]$ 。 本論文では新田の業務上犯罪概念を業務犯 (occupational crime) と同様の概念として捉えて いる。

（註 5 ）新田は、ホワイトカラー犯罪を業務上犯罪と 組織体犯罪に分類し、組織体犯罪を「組織体がそ の意思によって自己の利益目的実現のために、組 織的機能を活用して行う犯行」としている $[1]$ 。 しかし、法的判断においては、犯行が組織体の意 思によるのか、それとも一部の組織ないし成員の 意思によるものかは明らかにされないことが多い ため、これらを含めて、組織的犯罪と呼んでいる。

（註 6 ）ここでいう負の組織文化とは、犯罪を惹起す る性質を持つ組織文化のことである。

(註 7 ) これらの想定のうちの (4)は、前島の研究成果 を踏まえたものである。また(1)から(3)までは、新 田が解説した組織文化に関する理論や、上述の前 島の成果を参考に、著者が想定した仮説である。

(註 8 ) この項の記述は、特にことわらない限り、藤 原に依拠している。

（註 9 ）判決文、調書によれば、黄色ブドウ球菌とは 自然界に広範に存在している細菌で、人の手指、 生乳中などに含まれている。これが微量でも食品 に混入されれば $10^{\circ} \mathrm{C}$ を超えるにしたがって増殖し、 エンテロトキシンを産生する。な打黄色ブドウ球 菌の最適繁殖温度は $30^{\circ} \mathrm{C}$ から $40^{\circ} \mathrm{C}$ であるとされて いる。

（註10）札棍市衛生研究所 [15］によれば、エンテロ トキシンとは食中毒原因毒素のうち下痢を引き起 こすもののことである。エンテロトキシンは、 $100^{\circ} \mathrm{C}$ で30分間加熱しても毒性を失わず、消化酵 素や胃酸によって分解されることもない。

（註11）洗い汁とは、調書によれば、脱脂粉乳の製造 工程中の濃縮機および濃縮乳タンクを温水で洗浄 した際にできる、工程中に残っていた乳固形分が 溶解した水のことである。工場 Aでは、生産効率 を上げ、排水処理負担を軽減するために、洗い汁 を $5 \sim 10^{\circ} \mathrm{C}$ まで冷却した上で、脱脂粉乳の原料と して再利用していた。

(註12) 二次污染とは、調書によれば、殺菌工程より後 の段階での細菌污染のことをいう。製品から細菌 が発見されても、それが二次污染であれば食中毒 が発生する危険性はないと工場長は供述している。

（註13）調書の分析を通じては、工場 A内の組織文化 が新たに「形成された」ものなのか、元々存在し 
ていたものが「表出した」のかの判別がつかない。 したがってここでは何らかのきっかけで工場 Aに 十分な影響を持ちうる形で存在するようになった という意味で「現出された」という文言を用いた。 またこのような組織文化が、違法性を持つか否か の判別は、調書からはできなかったため、本論文 ではこれを「負の組織文化」と記載することを避

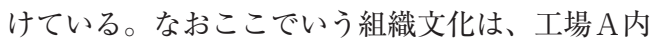
に拈いてのみ示唆されたものであり、業者 $\mathrm{A} の$ 組 織文化には言及していない。

\section{引用文献}

[1] 新田健一『組織とエリートたちの犯罪－その社 会心理学的考察』朝日新聞出版サービス、2001。

[2] Clinard, M. B. and Quinney, R., "Criminal Behavior System: A Typology (2ed) ” Holt Rinehart and Winston. 1973.

[3] Coleman, James "The Criminal Elite, The Sociology of White-Collar Crime" Martin's Press, Inc. 1994.（坂倉宏監訳『犯罪エリート』シュプ リンガー・フェアラーク東京、1996)

[4] Sutherland, E. H., “White Collar Crime”Dryden Press. 1949. (平野竜一・井口浩二訳『ホワイト · カラーの犯罪』岩波書店、1955)

[5]井上眞理子「アメリカに抢ける組織体犯罪研究」 『犯罪社会学研究』第13号、日本犯罪社会学会、 1988、pp.80-100。

[6] 前島賢土「証券会社社員の職務犯罪 - 証券業界 の業界下位文化」『犯罪社会学研究』第24号、日 本犯罪社会学会、1999、pp.96-112。

[7]前島賢土「銀行員の職務犯罪 - 銀行業界の業界
下位文化と犯罪」『犯罪社会学研究』第26号、日 本犯罪社会学会、2001、pp.94-114。

[8] 飯田史彦「研究ノート 企業文化とは何か」梅 澤正・上野征洋編『企業文化論を学ぶ人のため に』世界思想社、2000、pp.108-131。

[9]藤原邦達『雪印の落日 - 食中毒事件と牛肉偽装 事件 -』緑風出版、2002、pp.21-222。

[10］産経新聞取材班『ブランドはなぜ落ちたか一雪 印、そごう、三菱自動車事件の深層』角川書店、 2001。

[11] 判決文。

[12] 検察官面前供述調書。

[13］シャイン, E. H. 著、清水紀彦・浜田幸雄訳『組 織文化とリーダーシップーリーダーは文化をどう 変革するか』ダイヤモンド社、1989。

[14］平岡義和「経済犯罪の一要因としての犯罪意識 - 証券不祥事事件による例証」『犯罪社会学研究』 第18号、日本犯罪社会学会、1993、pp.138-154。

[15］札幌市衛生研究所『黄色ブドウ球菌エンテロト キシン』

(http://www.city.sapporo.jp/eiken/various/ poison/buentero.html (2009年 5 月30日確認))、

札幌市衛生研究所、2000。

[2008年 5 月 21日受付、2009年 5 月20日受理］

著者アドレス：

山本 祥平 (やまもと しょうへい)

s.yamamoto@ax2.ecs.kyoto-u.ac.jp 